
РАВНИ КОД ДЕЦЕ СТАРИЈЕГ ОСНОВНОШКОЛСКОГ УЗРАСТА

Марија Милетић ${ }^{1}$

\title{
PRESENCE OF SPINAL DISORDERS IN SAGITTAL PLANE AT CHILDREN OF SENIOR ELEMENTARY SCHOOL
} Marija Miletić

\section{Сажетак}

Циљ овог истраживања је био да се утврди присуство постуралних поремећаја у сагиталној равни, затим да се утврди однос постуралних поремећаја између дечака и девојчица, као и постојање релација морфолошког и постуралног простора испитаника.

Истраживање је спроведено на узоркуод 174 ученика V, VI и VII разреда. Од укупног броја испитаника, мушку популацију чинило је 94 испитаника, а женску популащију чинило је 80 испитаница. Узорак варијабли проиењен је помоћу две антропометријске мере, телесна висина (mm) и телесна тежина (kg), а за процену постуралног статуса у сагиталној равни примењене су варијабле за процену поремећаја кичменог стуба: кифотично ломе држање и лордотично лоше држағе тела. Резултати истраживања указују да је код већег броја испитаника обухваћених овим истраживањем утврђено ломе држање тела и изражен један или више поремећаја кичменог стуба.

Кључне речи: присутност, поремећај, кичмени стуб, ученици.

\section{Summary}

The aim of this study was to determine the presence of postural disorders in the sagittal plane, then to determine the ratio between postural disorders between boys and girls, as well as the relation of morphological and postural space of the subjects.

The survey was conducted on a sample of 174 students of the fifth, sixth and seventh grades. Of those who were surveyed the male population consisted of 94 patients, and a female population consisted of 80 subjects. The sample of variables was evaluated by the means of two anthropometric measures, body height $(\mathrm{mm})$ and the body weight $(\mathrm{kg})$, and to assess the status of the posture in the sagittal plane the following variables are applied for the assessment of disorders of the spine: poor kyphotic posture and poor lordotic posture. The survey results indicate that in a number of subjects included in this study the poor posture was present and one or more disorders of the spine were obvious.

Keywords: presence, disorder, spine, students.

\footnotetext{
${ }^{1}$ Марија Милетић, Мастер професор у физичком васпитању и спорту, Техничка школа у Књажевцу (Master of sport and physical education, Technical school Knjaževac, Knjaževac)
} 


\section{УВОД}

7 Ооком еволуције код човека су створене физиолошке кривине лордозе у вратном и лумбалном делу кичменог стуба, а кифоза у торакалном. Ове кривине у физиолошким границама су нормална појава док се њихово повећање и смањење сматра патолошким.

Лоше навике неправилног држања тела, неправилног седења, прекомерна тежина спортске торбе у периоду раста и развоја доводе до све већег броја постуралних поремећаја. Долази до скраћења и слабљења мускулатуре што доводи до мишићног дисбаланса који представља главни узрок за појаву и развој лошег држања тела, односно телесних деформитета.

Оно што посебно забрињава су резултати систематских прегледа телесног развоја и здравља ученика. Они показују да је у порасту број ученика са неправилним телесним држањем и телесним деформацијама.

Покретљивост кичме одвија се у три равни:фронталној,сагиталнојихоризонталној. Покрети у зглобовима кичменог стуба зависе од облика пршљенова. Тела пршљенова спојена су међупршљенским колутом и са два лигамента: lig. Interspinale et lig. Supraspinale. Discus intervertebralis je фиброкартилагинозни колут смештен између два тела пршљенова. Фиброзни прстен веома чврсто повезује епифизе два тела пршљена косим фиброзним сноповима. Nucleus pulposus је мекан и еластичан и налази се под јаким притиском, попут еластичне кугле размиче пршљенове и обезбеђује еластичност кичменог стуба. Међупршљенски колут обезбеђује покрете у свим правцима. Његова дебљина је већа у деловима кичменог стуба који су покретљивији (вратни и слабински), а мања у торакалном делу кичменог стуба.

У кичменом стубу се могу вршити прегибање (flexio), опружање (extensio), бочно прегибање (lateroflexio) и сукање (torsio). Флексија и екстензија врше се углавном у вратном и слабинском делу кичменог стуба. Код флексије лордоза вратног и слабинског дела нестаје и кичмени стуб добија облик лука. Код екстензије грудна кифоза се исправља а појачавају се лордозе слабинског и вратног дела. Лордоза је кривина кичменог стуба у сагиталној равни са конвекситетом напред. Кифоза је девијација кичменог стуба у сагиталној равни у торакалном делу са конвекситетом назад.

Предмет овог истраживања је утврђивање статуса и релација морфолошких карактеристика и постуралних поремећаја кичменог стуба код ученика мушког и женског пола основних школа у Књажевцу. Постурални статус се односи на постојање и заступљеност телесних деформитета у сагиталној равни.

\section{ЦИЉ ИСТРАЖИВАЫА}

Циљ овог истраживања је утврдити присуство постуралних поремећаја у сагиталној равни, утврдити однос постуралних поремећаја између дечака и девојчица, утврдити постојање релација морфолошког и постуралног простора испитаника.

\section{МАТЕРИЈАЛ И МЕТОДЕ}

Узорак испитаника чине ученици и ученице две основне школе у Књажевцу (ОШ „Вук Караџић” и ОШ „Дубрава”), који је обухватио 174 ученика (80 девојчица и 94 дечака) V, VI и VII разреда.

Узорак варијабли процењен је помоћу две антропометријске мере: телесна висина $(\mathrm{mm})$ и телесна тежина $(\mathrm{kg})$, а за процену постуралног статуса кифотично лоше држање и лордотично лоше држање.

Примењене су варијабле помоћу којих се врши процена:

1. Кифотично лоше држање (КЛД)

2. Лордотично лоше држање (ЛЛД)

Основна метода коришћена кроз овај истраживачки рад је метода соматометрија 
и соматоскопија, док је као помоћна коришћена статистичка метода, којом смо утврдили присуство деформитета кичменог стуба у сагиталној равни.

\section{РЕЗУЛТАТИ СА ДИСКУСИЈОМ}

Резултати добијени мерењем деце основношколског узраста приказани су следећим табелама, одвојено по школама, разредима, полу и по врсти деформитета.

Табела 1. Број и проиенат ученика V разреда ОШ „Вук Караиић“ са КЛД и ЛЛД и без деформитета.

\begin{tabular}{|c|c|c|c|c|c|c|c|c|}
\hline \multirow{4}{*}{$\begin{array}{l}\text { Ред. } \\
\text { број }\end{array}$} & \multicolumn{8}{|c|}{ ОШІ „Вук Карашић“ } \\
\hline & \multicolumn{8}{|c|}{ V разред } \\
\hline & \multirow{2}{*}{ Пол } & \multirow{2}{*}{$\begin{array}{r}\text { Укупно } \\
\text { ученика }\end{array}$} & \multicolumn{2}{|c|}{ кЛД } & \multicolumn{2}{|c|}{ ЛЛД } & \multicolumn{2}{|c|}{$\begin{array}{c}\text { Без } \\
\text { деформитета }\end{array}$} \\
\hline & & & Број & $(\%)$ & Број & $(\%)$ & Број & $(\%)$ \\
\hline 0 & 1 & 2 & 3 & 4 & 5 & 6 & 7 & 8 \\
\hline 1 & Девојчице & 18 & 3 & 16,6 & 6 & 33,3 & 9 & 50,0 \\
\hline 2 & Дечаци & 21 & 3 & 14,2 & 2 & 9,6 & 16 & 76,2 \\
\hline 3 & Укупно & 39 & 6 & 15,3 & 8 & 20,6 & 26 & 64,1 \\
\hline
\end{tabular}

На основу добијених резултата видимо да је кифотично лоше држање присутно код $16,6 \%$ испитаника женског пола а $14,2 \%$ код испитаника мушког пола (Табела 1).
Лордотично лоше држање је присутно код 33,3\% женског пола а 9,6\% код испитаника мушког пола.

Табела 2. Просечна висина (mm) и просечна тежина (kg) ученика V разреда ОШ „Вук Карацић“.

\begin{tabular}{|c|c|c|c|c|}
\hline \multirow{2}{*}{$\begin{array}{c}\text { Ред. } \\
\text { број }\end{array}$} & \multicolumn{4}{|c|}{ ОШ „Вук Карачић“ } \\
\cline { 2 - 5 } & \multirow{4}{|c|}{ V разред } \\
\cline { 2 - 5 } & Пол & Укупно & $\begin{array}{c}\text { Просечна } \\
\text { висина } \\
\text { (mm) }\end{array}$ & $\begin{array}{c}\text { Просечна } \\
\text { тежина (kg) }\end{array}$ \\
\hline 0 & 1 & 2 & 3 & 4 \\
\hline 1 & Девојчице & 18 & 1499,4 & 38,2 \\
\hline 2 & Дечаци & 21 & 1530,9 & 49,6 \\
\hline
\end{tabular}

Видимо да просечна висина код испитаника женског пола износи 1499,4 mm, а код испитаника мушког пола износи 1530,9 mm (Табела 2).
Просечна телесна тежина код испитаника женског пола износи $38,2 \mathrm{~kg}$, а код испитаника мушког пола 49,6 kg. 
Табела 3. Број и проценат ученика VI разреда ОШ „Вук Каращић“ са КЛД и ЛЛД и без деформитета.

\begin{tabular}{|c|c|c|c|c|c|c|c|c|}
\hline \multirow{4}{*}{$\begin{array}{l}\text { Ред. } \\
\text { број }\end{array}$} & \multicolumn{8}{|c|}{ ОШІ „Вук Караџић“ } \\
\hline & \multicolumn{8}{|c|}{ VI разред } \\
\hline & \multirow[t]{2}{*}{ Пол } & \multirow[t]{2}{*}{$\begin{array}{c}\text { Укупно } \\
\text { ученика }\end{array}$} & \multicolumn{2}{|c|}{ кЛД } & \multicolumn{2}{|c|}{ ЛЛД } & \multicolumn{2}{|c|}{$\begin{array}{c}\text { Без } \\
\text { деформитета }\end{array}$} \\
\hline & & & Број & $(\%)$ & Бро & $(\%)$ & Број & $(\%)$ \\
\hline 0 & 1 & 2 & 3 & 4 & 5 & 6 & 7 & 8 \\
\hline 1 & Девојчице & 30 & 10 & 33,3 & 8 & 26,7 & 12 & 40,0 \\
\hline 2 & Дечаци & 35 & 10 & 28,6 & 6 & 17,1 & 19 & 54,3 \\
\hline 3 & Укупно & 65 & 20 & 30,7 & 14 & 21,6 & 31 & 47,7 \\
\hline
\end{tabular}

Видимо да је кифоза присутна код 33,3\% испитаника женског пола, а 28,6\% код испитаника мушког пола (Табела 3).
Лордоза је присутна код 26,7\% испитаника женског пола, а 17,1\% код испитаника мушког пола.

Табела 4. Просечна висина (mm) и просечна тежина $(\mathrm{kg})$ ученика VI разреда ОШ „Вук Карацић”.

\begin{tabular}{|c|c|c|c|c|}
\hline \multirow{2}{*}{$\begin{array}{c}\text { Ред. } \\
\text { број }\end{array}$} & \multicolumn{4}{|c|}{ ОШІ „Вук Караџић” } \\
\cline { 2 - 5 } & Пол & Укупно & $\begin{array}{c}\text { Просечна } \\
\text { висина } \\
\text { (mm) }\end{array}$ & $\begin{array}{c}\text { Просечна } \\
\text { тежина (kg) }\end{array}$ \\
\hline 0 & 1 & 2 & 3 & 4 \\
\hline 1 & Девојчице & 30 & 1541,0 & 46,9 \\
\hline 2 & Дечаци & 35 & 1510,8 & 44,2 \\
\hline
\end{tabular}

Просечна висина испитаника женског пола 1541,0 mm, а мушког пола 1510,8 mm (Табела 4).
Просечна телесна тежина испитаника женског пола је 46,9 kg, а мушког пола 44,2 $\mathrm{kg}$.

Табела 5. Број и проиенат ученика VII разреда ОШ „Дубрава” са КЛД и ЛЛД и без деформитета.

\begin{tabular}{|c|c|c|c|c|c|c|c|c|}
\hline \multirow{4}{*}{$\begin{array}{l}\text { Ред. } \\
\text { број }\end{array}$} & \multicolumn{8}{|c|}{ ОШ ,Дубрава" } \\
\hline & \multicolumn{8}{|c|}{ VII разред } \\
\hline & \multirow[t]{2}{*}{ Пол } & \multirow{2}{*}{$\begin{array}{c}\text { Укупно } \\
\text { ученика }\end{array}$} & \multicolumn{2}{|c|}{ кЛД } & \multicolumn{2}{|c|}{ ЛЛД } & \multicolumn{2}{|c|}{$\begin{array}{c}\text { Без } \\
\text { деформитета }\end{array}$} \\
\hline & & & Број & $(\%)$ & Број & $(\%)$ & Број & $(\%)$ \\
\hline 0 & 1 & 2 & 3 & 4 & 5 & 6 & 7 & 8 \\
\hline 1 & Девојчице & 32 & 6 & 18,7 & 10 & 31,2 & 16 & 50,0 \\
\hline 2 & Дечаци & 38 & 7 & 18,4 & 01 & 2,6 & 30 & 78,9 \\
\hline 3 & Укупно & 70 & 13 & 18,6 & 11 & 15,7 & 46 & 65,7 \\
\hline
\end{tabular}

Кифотично лоше држање има 18,7\% испитаника женског пола, а 18,4\% испитаника мушког пола (Табела 5).
Лордотично лоше држање има $31,2 \%$ испитаника женског пола, а 2,6\% испитаника мушког пола. 
Табела 6. Просечна висина (mm) и просечна тежина $(\mathrm{kg})$ ученика VII разреда ОШ „Дубрава”.

\begin{tabular}{|c|c|c|c|c|}
\hline \multirow{2}{*}{$\begin{array}{c}\text { Ред. } \\
\text { број }\end{array}$} & \multicolumn{4}{|c|}{ ОШ ,Дубрава" } \\
\cline { 2 - 5 } & Пол & ВИИ разред \\
\hline 0 & 1 & 2 & $\begin{array}{c}\text { Просечна } \\
\text { висина } \\
\text { (mm) }\end{array}$ & $\begin{array}{c}\text { Просечна } \\
\text { тежина (kg) }\end{array}$ \\
\hline 1 & Девојчице & 32 & 1608,6 & 4 \\
\hline 2 & Дечаци & 38 & 1621,4 & 50,9 \\
\hline
\end{tabular}

Видимо да просечна висина код испитаника женског пола износи $1608,6 \mathrm{~mm}$, а код испитаника мушког пола износи 1621,4 mm (Табела 6).

Табела 7. Број и проценат ученика V, VI, VII разреда са кифотичним и лордотичим лошим држањем према полу.

\begin{tabular}{|c|c|c|c|c|c|c|c|c|c|}
\hline \multirow{3}{*}{$\begin{array}{l}\text { Ред. } \\
\text { број }\end{array}$} & \multirow{3}{*}{ Разред } & \multicolumn{3}{|c|}{ Девојчице } & \multicolumn{3}{|c|}{ Дечаци } & \multirow{2}{*}{\multicolumn{2}{|c|}{$\begin{array}{c}\text { Укупно } \\
\text { деформитета }\end{array}$}} \\
\hline & & \multirow{2}{*}{$\begin{array}{l}\text { Укупно } \\
\text { ученика }\end{array}$} & \multicolumn{2}{|c|}{ Укупно п.п. } & \multirow{2}{*}{$\begin{array}{c}\text { Укупно } \\
\text { ученика }\end{array}$} & \multicolumn{2}{|c|}{ Укупно п.П. } & & \\
\hline & & & Број & $\%$ & & Број & $\%$ & Број & $\%$ \\
\hline 0 & 1 & 2 & 3 & 4 & 5 & 6 & 7 & 8 & 9 \\
\hline 1 & $\mathbf{V}$ & 18 & 09 & 50,0 & 21 & 05 & 23,8 & 14 & 35,8 \\
\hline 2 & VI & 30 & 18 & 60,0 & 35 & 16 & 45,7 & 34 & 52,3 \\
\hline 3 & VII & 32 & 16 & 50,0 & 38 & 08 & 21,1 & 24 & 34,2 \\
\hline 4 & Укупно & 80 & 43 & 53,7 & 94 & 29 & 30,8 & 72 & 41,3 \\
\hline
\end{tabular}

На основу добијених резултата (Табела 7) видимо да је кифотично и лордотичо лоше држање присутно код $41,3 \%$ ученика. Код

испитаника женског пола износи 53,7\%, док код испитаника мушког пола износи $30,8 \%$. ника женског пола износи 50,9 kg, а код испитаника мушког пола 54,7 kg.

\section{Табела 8}

\begin{tabular}{|c|c|c|c|c|c|}
\hline $\begin{array}{c}\text { Ред. } \\
\text { број }\end{array}$ & Разред & $\begin{array}{c}\text { Просечна } \\
\text { висина (mm) }\end{array}$ & $\begin{array}{c}\text { Просечна } \\
\text { телесна тежина } \\
\mathbf{( k g )}\end{array}$ & $\begin{array}{c}\text { Укупан } \\
\text { број деце са } \\
\text { КЛД }\end{array}$ & $\begin{array}{c}\text { Укупан } \\
\text { број деце са } \\
\text { ЛЛД }\end{array}$ \\
\hline 0 & 1 & 2 & 3 & 4 & 5 \\
\hline 1 & V & 1516,4 & 44,4 & 6 & 8 \\
\hline 2 & VI & 1524,7 & 45,4 & 20 & 14 \\
\hline 3 & VII & 1615,6 & 52,9 & 13 & 11 \\
\hline
\end{tabular}

Видимо да се код ученика V и VI разреда ca порастом телесне висине и тежине повећава и присутност деформитета, док је код ученика VII разреда присутан мањи број постуралних поремећаја (Табела 8).

Резултати овог истраживања показују да је од укупног броја испитаника $41,3 \%$ са постуралним поремећајима кичменог стуба у сагиталној равни.
Присутност постуралних поремећаја кичменог стуба је већа код ученика женског пола и износи $53,7 \%$, док код ученика мушког пола износи $30,8 \%$.

Ученици V и VI разреда с израженијом телесном висином и телесном тежином имали су одређене промене положаја кичменог стуба у грудном и слабинском делу. Код ученика VII разреда броја телесних деформитета је мањи. 
Кичмени стуб у сагиталној равни показује нормалне физиолошке кривине у вредности од 20 до 35 степени са теменом кривине у нивоу VII грудног пршљена. Физиолошка уклињеност пршљенова може се толерисати до 5 степени (Živković, 1998).

Преваленца лошег држања тела код испитиване популације школске деце у Чешкој Републици је 38,3\% (Kratenova i sar., 2007), при чему дечаци имају лошије држање тела у односу на девојчице. Код деце са лошим постуралним статусом чешће се јавља главобоља и бол у вратном и лумбалном делу кичменог стуба.

У раном адолесцентном периоду долази до бурних анатомско-физиолошко-хормоналних промена које утичу на интезиван раст и развој организма, при чему кости расту брже него мишићи који се услед тога затежу и долази до повећања тонуса мускулатуре читавог тела (Medved, 1987).

\section{ЗАКЈУУЧАК}

На основу добијених резултата утврђено је да је проценат деце са правилним др- жањем тела већи од процента деце код којих су присутни постурални поремећаји кичменог стуба.

Стање у школству је незадовољавајуће по питању здравља ученика, јер се све већа пажња поклања интелектуалним активностима, а на штету правилног раста и развоја. Како лоша држања представљају по правилу почетну фазу развоја неког деформитета, применом корективне гимнастике се могу постићи неки позитивни ефекти јер се у овим случајевима ради углавном о попуштању, односно слабостима активних снага организма.

Комплексом датих вежби треба да се обухвати цела мускулатура, али се посебна пажња усмерава на инсуфицијентне мишиће. Синхронизовано учешће свих фактора који су одговорни за правилан развој дечијег организма у целини може довести до жељених позитивних учинака.

Образац доброг држања тела доприноси правилном расту и развоју деце уз позитивну рефлексију на здравље и културу живљења.

\section{ЛИТЕРАТУРА}

1. Daglas D. Routine scoliosis screening of dubious value. Pediatrics, 2008.

2. Ilić D. Korektivna gimnastika. Praktikum.

Fakultet sporta i fizičkog vaspitanja.

Beograd, 2012.

3. Kratenova J, Zejglicova K, Mali M, Filipova V. Prevalence and Risk Factors of Poor Posture in School Children in the Czech Republic. Journal of School Health, 2007; 77(3): 131-137.
4. Medved R. Sportska medicina. JUMENA
- Jugoslovenska medicinska naklada, Zagreb, 1987.
5. Živković D. Primena korektivnih aktivnosti u saniranju osnovnih poremećaja na kičmenom stubu u sagitalnoj ravni. Magistarski rad. Fakultet za fizičko vaspitanje. Beograd, 1983.
6. Živković D. Teorija i metodika korektivne gimnastike. SIA, Niš, 1998. 7. Živković D. Osnove kineziologije sa elementima kliničke kineziologije. Fakultet sporta i fizičkog vaspitanja, Niš, 2009.

Контакт: Марија Милетић, Мастер спорта и физичког васпитања, Техничка школа у Књажевцу, Књажевац, Сарајевска 13, тел: 0648908677 , e-mail: marijamacamiletic@gmail.com 